\title{
Workplace violence: legislation, public policies and possibility of advances for health workers
}

\author{
Violência no trabalho: legislação, políticas públicas e possibilidade de avanços para trabalhadores da saúde \\ Violencia laboral: legislación, políticas públicas y posibilidad de avanzar para los trabajadores de salud
}

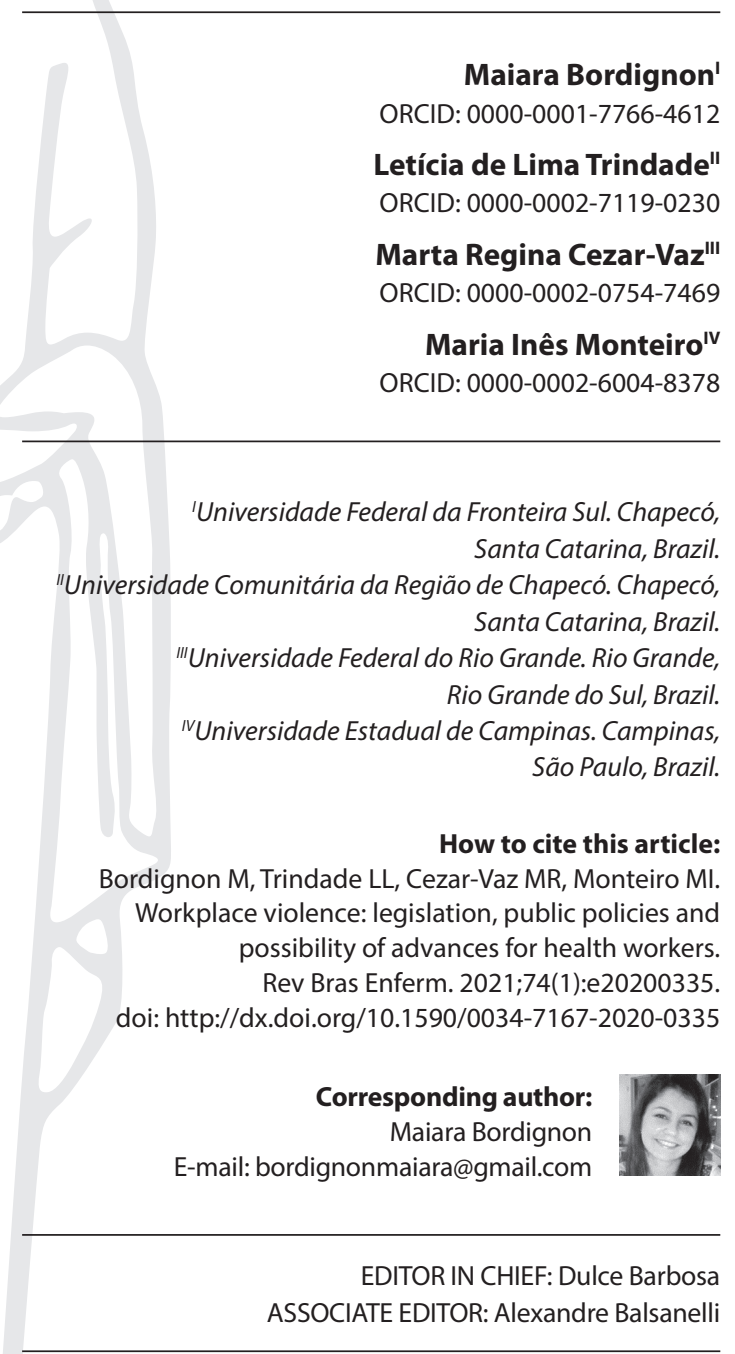

Submission: $04-22-2020$

Approval: $09-20-2020$

\begin{abstract}
Objectives: to discuss specific laws and public policies for workplace violence in the health sector, highlighting possibilities for the collective confrontation of this phenomenon in Brazil. Methods: this is a reflective and argumentative study that refers to some previous experiences regarding the implementation of legal aspects to curb workplace violence directed at health professionals. Results: there are experiences regarding the existence of legislation or public policies to specifically contain workplace violence in the health sector, but these are still restricted to some places or countries. The literature provides resources for developing specific strategies for managing this phenomenon, highlighting prevention programs and conducts for case management. Final Considerations: implementation of legal aspects or public policies at the municipal, regional, state and/or national level is a strategy with potential to confront workplace violence in health services in a collective and sustainable way.

Descriptors: Workplace Violence; Occupational Health; Health Personnel; Legislation;
\end{abstract} Public Policy.

\section{RESUMO}

Objetivos: discutir sobre legislações e políticas públicas específicas para a violência no trabalho em saúde, destacando possibilidades para o enfrentamento coletivo deste fenômeno no Brasil. Métodos: trata-se de um estudo reflexivo e argumentativo, que referencia algumas experiências prévias quanto à implementação de aspectos legais para coibir a violência no trabalho dirigida aos profissionais de saúde. Resultados: há experiências com relação à existência de legislação ou políticas públicas para conter especificamente a violência no trabalho no setor saúde, mas essas ainda se restringem a alguns locais ou países. A literatura fornece subsídios para o desenvolvimento de estratégias específicas para gerenciamento deste fenômeno, ressaltando os programas de prevenção e condutas para manejo dos casos. Considerações Finais: a implementação de aspectos legais ou de políticas públicas em âmbito municipal, regional, estadual e/ou nacional é uma estratégia com potencial para enfrentamento da violência no trabalho em saúde, de maneira coletiva e sustentável. Descritores: Violência no Trabalho; Saúde do Trabalhador; Trabalhadores da Saúde; Legislação; Políticas Públicas.

\section{RESUMEN}

Objetivos: discutir legislación y políticas públicas específicas para la violencia ocupacional en salud, destacando las posibilidades para el enfrentamiento colectivo de este fenómeno en Brasil. Métodos: se trata de un estudio reflexivo y argumentativo, que hace referencia a algunas experiencias previas sobre la implementación de aspectos legales para frenar la violencia laboral dirigida a los profesionales de la salud. Resultados: existen experiencias sobre la existencia de legislación o políticas públicas para contener específicamente la violencia laboral en el sector salud, pero aún están restringidas a algunas localidades o países. La literatura apoya el desarrollo de estrategias específicas para el manejo de este fenómeno, destacando los programas de prevención y conductas para el manejo de casos. Consideraciones Finales: la implementación de aspectos legales o políticas públicas a nivel municipal, regional, estatal y/o nacional es una estrategia con potencial para enfrentar la violencia en el trabajo en salud, de manera colectiva y sustentable.

Descriptores: Violencia Laboral; Salud Laboral; Personal de Salud; Legislación; Política Pública. 


\section{INTRODUCTION}

Workplace violence is not a recent social phenomenon, but since 1980 it has gained greater public visibility with news reports on incidents of homicide at the workplace in areas that are not recognized as being under high risk of violence ${ }^{(1)}$. Currently it is known that, in general, there is a significant risk of workplace violence events in health facilities ${ }^{(2)}$. Although conceptualizing workplace violence is a challenge in the face of cultural and behavioral influences, as well as theoretical conceptions on the subject, it is understood that such events are incidents in which workers are targets of offensive, aggressive or threatening behavior under circumstances that hold a relationship with the work to be performed ${ }^{(3)}$. This definition includes the different characteristics of acts of violence that are taken into consideration in attempts to propose terms and concepts for their variation $s^{(3)}$. There are different terms or constructs in the literature that are proposed to specify the types of violence, such as bullying, sexual harassment, assault, threat, among others ${ }^{(3)}$.

In this sense, it is identified in studies that workplace violence has occurred in a variety of ways in different professional strata and health work environments, including Primary Health Care (PHC) services, hospital units, emergency services, mental health services, and radiology services ${ }^{(4-5)}$. Research mentions that the organizational dimensions of health services and the nature of work, which includes the workplace and professional practice, are associated factors to the occurrence of labor violence ${ }^{(4)}$. The fact that health professionals are exposed to various situations that are among the risk factors for workplace violence - such as direct relationships with distressed and frustrated people, high levels of stress, and the provision of assistance in territories that often hold conflict areas or drug trafficking - highlights the importance of the theme for this professional category ${ }^{(3,6)}$.

Evidence indicates that health professionals usually suffer violence perpetrated by patients in the form of threats, verbal abuse and, less frequently, physical violence ${ }^{(5-6)}$. Research with health professionals working in PHC in Brazil showed that $69.8 \%$ of them suffered workplace violence in the previous year ${ }^{(6)}$. In that survey, $71.6 \%$ of violent events in the last year presented healthcare service users as aggressors; $6.4 \%$ were practiced by patients' family members/companions; $11 \%$ by coworkers; and $9.2 \%$ by managers ${ }^{(6)}$. It should be noted that the studies described acts of violence committed by coworkers or managers, which were characterized as bullying, verbal abuse or threats, thus reflecting difficulties in interprofessional relationships ${ }^{(5-6)}$.

There are records of cases of violence in different countries ${ }^{(4-7)}$. A systematic review of the literature summarized evidence regarding the prevalence of workplace violence in health services as practiced by patients or visitors ${ }^{(7)}$. This study highlighted that, of 331,544 participants, $61.9 \%$ reported exposure to workplace violence $^{(7)}$. The researchers also mentioned the high prevalence of workplace violence especially in Asia and North America, in emergency and psychiatry sectors and, regarding affected professional categories, towards nurses and medical doctors ${ }^{(7)}$.

Studies indicate that nursing professionals - who make up the frontline in health care provision - are oftentimes the most frequent victims of workplace violence ${ }^{(4,6-7)}$. Data from a study with nurses from New Jersey (United States of America-USA) showed that $57.8 \%$ of participants had suffered verbal abuse from patients or their family members in the last 12 months, $52.3 \%$ received threats, and $38.3 \%$ were victims of physical aggression ${ }^{(5)}$. In the same study, $30.1 \%$ of nurses reported being bullied by a coworker or manager, followed by $25.7 \%$ suffering verbal abuse and $19.8 \%$ receiving threats ${ }^{(5)}$.

Currently it is known that the occurrence of workplace violence in the health sector makes professionals and their employer institutions highly predisposed to suffer various consequences ${ }^{(3-4)}$. It is evident in the literature that experiences of workplace violence in health care can result in psychic consequences, such as depressive symptoms, anxiety, post-trauma disorders and stress ${ }^{(3-4)}$. At the organizational level, the impact of violence also can be extensive, as its presence is able to affect team motivation and performance, as well as decrease the quality of care $^{(3-4)}$.

This outlook demonstrates the need to reflect on the strategies at use to combat workplace violence in the health sector, especially on collective ones. A systematic review of the literature, conducted with the objective of describing scientific reports that analyzed workplace violence in health services, points towards individual and organizational mechanisms for coping with the phenomenon, mentioning social support and training as organizational mechanisms ${ }^{(4)}$. However, a study conducted with health professionals in Brazil showed that violence was associated with a negative evaluation of relationships between coworkers and managers, which may have repercussions on the (in)existence of social support at work to cope with this issue ${ }^{(6)}$.

In this sense, researchers also describe limitations resulting from the absence of workflows instituted in the healthcare network to indicate the recommended conducts in cases of workplace violence $^{(6)}$. The absence of structured guidelines and workflows to care for the health of workers who are victims of workplace violence often directs them to seek individual strategies with their own resources to address $i^{(6)}$.

The results evidenced in studies have enabled workplace violence to become a phenomenon that is understood and discussed more and more among research teams, institutions, professional councils, policy managers and society ${ }^{(1)}$. As consequence of better understanding the phenomenon and its extent, different efforts to act against workplace violence directed at health professionals are identified as time goes by, among which legislative and regulatory efforts stand out ${ }^{(1)}$.

Strategies for the protection and promotion of workers' health have been instituted in Brazil, as well as actions aimed at social awareness and minimization of workplace violence ${ }^{(8)}$. On the other hand, it is recognized that there is a necessity to promote actions constituting a powerful frontline to curb workplace violence in the health sector in a broad and sustainable way in many countries, including the Brazilian context.

Thus, this reflection focuses on addressing legal aspects and/ or public policies related to workplace violence in the health sector, as they may represent possible strategies or means to confront it in a collective approach. That approach, furthermore, comprises the existence of articulated fronts involving public policy formulators, managers and sectors of society in favor of adopting measures for prevention and management of workplace violence in health sectors. 


\section{OBJECTIVES}

To discuss specific laws and public policies for workplace violence in the health sector, highlighting possibilities for the collective confrontation of this phenomenon in Brazil.

\section{METHODS}

This is a reflective and argumentative study that, by referencing experiences of some locations and organizations regarding the elaboration and implementation of legal aspects or public policies to curb violence in health work, seeks to promote deliberations that culminate or support proposals of this nature, especially in Brazil, so that they integrate and extend measures to prevent and manage cases of violence perpetrated against health workers. This study presents current arguments that highlight possibilities to collectively face violence that affects health professionals in the performance of their work.

\section{Legal aspects and policies against workplace violence in the health sector: possibilities to advance}

Several cases of workplace violence against health professionals are recorded in Latin America and worldwide ${ }^{(4-7)}$. The expressive existence of violence in the health work environment calls for effective and sustainable measures to avoid the continuation of this problem; above all, measures that favor collective confrontation.

In this sense, some experiences are herein addressed regarding the existence of legal aspects or policies to avoid and curb violence against health professionals. Some States and organizations share strategies that can support the construction of new proposals in places where there are no specific laws, regulations or policies to prevent workplace violence in healthcare ${ }^{(2)}$. It is understood that workplace violence is a problem that is evidenced worldwide and that can be fought through collective efforts ${ }^{(2)}$.

In the 1990s, the first efforts were made to create and enact legal aspects or administrative regulations to specifically prevent or decrease the incidence of workplace violence in the health sector by imposing requirements to employer organizations ${ }^{(1)}$. These legal instruments addressed labor violence under a comprehensive perspective or targeted specific workplaces or professions, including requirements for employers in order to face violence in the context of health services ${ }^{(1)}$.

The State of California (U.S.A.) pioneered these efforts when it demanded, in 1993, the development and maintenance of programs for violence prevention from health services ${ }^{(2)}$. Other U.S. states such as Washington, New York, New Jersey and Connecticut have also established requirements for health services, demanding the existence of programs aimed at preventing workplace violence ${ }^{(1-2)}$. In this sense, it is noteworthy that the requirements may differ between state laws according to the purpose and scope desired by the State, considering sectors and work environments ${ }^{(2)}$.

In 2011, the State of New Jersey (USA) enacted its Violence Prevention in Health Care Facilities Act, which began to require intensive care, mental health and elderly care services to develop programs that included: committees, policies and written plans for the prevention of workplace violence as components; assessment of risks and training about the theme; and event reporting and post-incident response systems ${ }^{(5)}$. A period was also established for the affected institutions to fully comply with all the components in accordance with the $\mathrm{Act}^{(5)}$.

Citing the New Jersey Violence Prevention in Health Care Facilities Act (USA), authors ${ }^{(5)}$ mention components for training that relate both to the prevention of violent events at work and to actions when facing aggression. This set of components includes the review of safety policies focused on workplace violence, analysis of predictive aspects of aggression cases, provision of the health history of patients with violent behavior, and methods to prevent or contain these behaviors; all of that in addition to self-defense training, location of safety devices and how to operate them, procedures for reporting events, and resources for professionals who are victims of violence ${ }^{(5)}$.

Referring to the regulations implemented by the province of British Columbia, Canada, in 1993, an author mentions elements that comply with those described above, among which is highlighted the responsibility of employers to establish strategies to eliminate or decrease the risk of violence when it is identified, their duty to report incidents to the Workers' Compensation Board of British Columbia, and the presence of requisite training of workers ${ }^{(1)}$.

As of 2017, a new regulation of the California Occupational Health and Safety Administration (USA) was enacted and health services began to carry out its requirements ${ }^{(9)}$. In this sense, an author ${ }^{(9)}$ points out that the regulation included conditions for health institutions in relation to the implementation of written plans that focused on violence prevention, the increased notification of incidents, and requirements related to staff training, all as a response to the increasing number of cases of workplace violence in health services.

Scholars highlight the relevance of training actions that are interactive and aligned with reality, that improve knowledge and skills among the professionals so violent events do not occur against them or their team at work, and that assist them in preventing or neutralizing violence ${ }^{(5,9-10)}$. Research with licensed nurses in New Jersey (USA) showed that those who had access to training with at least $80 \%$ of the components indicated by the legislation were more likely to feel safer at work, suggesting that the provision of information about the phenomenon is important in programs against workplace violence in the health sector ${ }^{(5)}$.

Despite efforts in different countries or regions ${ }^{(1-2,5,9)}$, many locations in the world do not have legislation or public policies to ensure specific strategies for preventing violence against health professionals ${ }^{(1)}$. Thus, there are places where the mechanisms for protecting the safety and health of these workers still present weaknesses in their structure and action, including in developing programs to prevent or curb workplace violence.

In this sense, it is central to identify legal aspects/regulations and specific policies as possibilities that direct institutions towards workplace violence prevention in health services, assisting them in the process of integrating actions against violence and protection of workers to their institutional and collaborative projects. Authors emphasize that regulations are means of ensuring that health institutions enact programs aimed at preventing the exposure of professionals to violence during the performance of their work ${ }^{(5)}$.

Concerning Brazil, it is worth mentioning the existence of the Brazilian National Policy of Workers' Health, which provides 
for the recognition of a set of work-related events, including situations of violence ${ }^{(8)}$. The notification of cases of workplace violence currently contributes to increase visibility to workers' health and safety issues, as well as subsidizes actions related to the prevention and confrontation of violence ${ }^{(8)}$. On the other hand, despite the advances in the amount of evidence regarding workplace violence in the health sector and in the implementation of actions for its prevention, new incidents of violence against professionals in the area amass in the country. Therefore, it is considered necessary that specialized strategies be promoted in health work environments, allowing to face the phenomenon collectively and lastingly towards a culture of peace.

In this perspective, health institutions have a fundamental role in preventing workplace violence and supporting their workers, which places them in a prominent position in legal aspects or policies that aim to curb workplace violence in health services ${ }^{(1-2,5,9)}$. Several of these aspects impose requirements to be met by health institutions in order to prevent violence, and the existence of prevention programs is often among the requirements ${ }^{(1-2,5,9)}$.

Workplace violence prevention programs can be part of broader health and safety plans in the institution, thus making up a comprehensive risk management system for the safety of health professionals, which includes strategies related to workplace violence and other elements, such as: patient management (ergonomic aspects), transmission of pathogens, and work accidents $^{(2,10)}$. These programs can be based on tools such as PlanDo-Study-Act (PDSA), which allows continuous monitoring of the environment and its possible internal risks and in the surrounding community, so that changes can be defined and implemented, thus building experiences from them ${ }^{(2,10)}$. In addition, successful management systems usually consist of six steps ${ }^{(2)}$ :

1. management commitment to health and safety: in this component, managers take health and safety in the institution as a priority and show this commitment through their communication, by setting goals and offering resources and support, in addition to preparing documents that present area performance;

2. participation of workers: professionals have different knowledge about the work environment and it is important to involve them in all aspects of the program, encouraging them to report concerns and maintain open communication with management;

3. environment analysis with identification of labor risks or hazards: initial evaluation is carried out, followed by regular reassessments, to continuously identify risks in the workplace through the existence of established processes or procedures;

4. prevention and control of risks or hazards: strategies are implemented to eliminate or mitigate the identified risks in the workplace and achieve the established goals; in this context, implementation-related progress is analyzed;

5. health and safety training: all professionals are trained to recognize and control risks, as well as their responsibilities within the program;

6. program evaluation: through defined processes and records, program implementation and its performance are monitored in order to identify fragile points and possibilities to improve it; these factors culminate in the adoption of actions to promote necessary improvements.

In this perspective, it is important that institutions internally promote the culture of violence prevention, demonstrating commitment to the existence and quality of a safe working environment for their workers and patients, with reduced risk of damage ${ }^{(2)}$. Establishing a program to prevent violence against the institution's professionals is a way to manifest this commitment ${ }^{(10)}$. Moreover, investments in the safety of professionals collaborate with the promotion of patient safety and generally result in improvements in the provision of health care, which are relevant aspects for the recognition health institutions today ${ }^{(2)}$.

Based on previous experiences referenced in this study ${ }^{(1-2,5,9)}$ it is understood that the organization of specific legal aspects and public policies for the prevention of workplace violence in the health sector may take the following elements in consideration, as fitting:

a) presentation of the adopted concepts of workplace violence to define cases;

b) description of the scope of the document, its reach, objectives and deadlines;

c) information for the composition of violence prevention plans, indicating minimum and fundamental elements that should be incorporated during its elaboration and implementation, in addition to deadlines and regulatory mechanisms. If relevant, description of the implications of non-compliance with items or non-adherence, and vice versa;

d) encouraging institutional plan development that include the collaboration of other institutions or sectors of society to build joint strategies to promote the culture of non-violence;

e) description of specific measures for each type of workplace violence, considering the work context in which it occurs and the gradual protection of health workers;

f) strengthening the records and data management of workplace violence cases as a resource to identify victims, provide support and monitor the phenomenon in its multiple facets over time in relation to described and implemented strategies.

In this sense, an author ${ }^{(9)}$ points out that no incident should be free of records, whether caused intentionally or in relation to a patient's health (e.g., violence generated by patients in mental confusion or delirium). It is important that institutional leaders and workers' unions support the systems, even regarding optional anonymity, so that they are structured in a way that promotes trust among workers and allows transparent reports on violence for analysis by the responsible team or committee ${ }^{(10)}$.

It is considered that the implementation of legal aspects and public policies aimed at curbing workplace violence in healthcare environments can contribute to inform workers, employers and the general public about this phenomenon and the possible means for its prevention in professional practice ${ }^{(1)}$. It is understood that increased awareness of all parties about this problem may increase efforts in an attempt to reduce it ${ }^{(1)}$.

In this context, it is understood that there have been advances in relation to strategies for workplace violence prevention in health 
services over the years, more markedly in some places or regions. However, in addition to these strategies, new actions need to be adopted considering the existing possibilities to advance towards avoiding the incidence of cases of violence and towards better handling them when they occur. It is important that innovative actions to collectively and permanently confront this phenomenon are intensified, to ensure safety and support to workers in the health sector. One possibility of intervention is the implementation of specific legal aspects or public policies that, as demonstrated in this study, have been adopted in some locations to conduct measures to prevent and manage workplace violence. The need to intensify the debate on the implementation of measures that promote the collective confrontation of labor violence in the health sector in Brazil is reiterated, because Brazilian evidence about this phenomenon shows expressive occurrence of cases of workplace violence, and weaknesses in dealing with it are identified.

\section{FINAL CONSIDERATIONS}

Workplace violence in the health sector is a globally-identified phenomenon today. Cases of violence are often alluded to by research, the media and the workers themselves, along with their implications to the health of those involved and to the services themselves. Therefore, strategies to prevent workplace violence in healthcare environments are important in Brazil and worldwide. Thus, emphasis is due on the formulation of specific legal aspects and policies for workplace violence prevention in the health sector, which can be implemented at the municipal, regional, state and/or national levels to act against this phenomenon in a comprehensive and sustainable manner.
In this sense, previous experiences in some localities and organizations that implemented legislation, regulations or policies to prevent workplace violence in the health area were addressed in this study. Such experiences stand out as strategies with emphasis on collective efforts that, given their characteristics, could more appropriately manage this global problem. Therefore, legal aspects and policies are identified as possibilities to be intensified in order to collectively confront workplace violence in health services in Brazil.

The limitation of this study is the impossibility of analyzing on-site strategies on the legal aspects or policies of workplace violence prevention, because they were not identified in the literature. These data or strategies could also support reflection and provide ways to confront this phenomenon.

This paper is expected to foster analyses and discussions regarding the adoption of collective measures for the prevention and management of workplace violence in health the sector and, thus, encourage public policy formulators to understand, in an expanded way, how this fact is configured in different places or countries, according to the singularity of the contexts and individuals involved in episodes of violence. Regarding the planning and implementation of practices in health care, in this case particularly with emphasis on workers' health, it is considered essential that there be concern regarding access to national and international literature to identify best practices regarding prevention and management of workplace violence in the health sector, aiming to discuss them in the local and/or national context.

It is considered that this paper can also broaden reflection on the theme among other professional categories that regularly experience events of workplace violence, such as education and public security professionals.

\section{REFERENCES}

1. Barish RC. Legislation and regulations addressing workplace violence in the United States and British Columbia. Am J Prev Med. 2001;20(2):149-54. doi: 10.1016/s0749-3797(00)00291-9

2. Occupational Safety and Health Administration. Workplace violence prevention and related goals: the big picture [Internet]. 2015[cited 2020 Apr 10]. Available from: https://www.osha.gov/Publications/OSHA3828.pdf

3. Di Martino V. Workplace violence in the health sector. Relationship between work stress and workplace violence in the health sector [Internet]. Geneva; 2003[cited 2020 Apr 10]. Available from: https://www.who.int/violence_injury_prevention/violence/interpersonal/en/ WVstresspaper.pdf

4. Palma A, Ansoleaga E, Ahumada M. Workplace violence among health care workers. Rev Méd Chile. 2018;146(2):213-22. doi: 10.4067/ s0034-98872018000200213

5. Ridenour ML, Hendricks S, Hartley D, Blando JD. Workplace violence and training required by new legislation among NJ Nurses. J Occup Environ Med. 2017;59(4):e35-e40. doi: 10.1097/JOM.0000000000000973

6. Sturbelle ICS, Pai DD, Tavares JP, Trindade LL, Riquinho DL, Ampos LF. Workplace violence in Family Health Units: a study of mixed methods. Acta Paul Enferm. 2019;32(6):632-41. doi: 10.1590/1982-0194201900088

7. Liu J, Gan Y, Jiang H, Li L, Dwyer R, Lu K, et al. Prevalence of workplace violence against healthcare workers: a systematic review and metaanalysis. Occup Environ Med. 2019;76(12):927-37. doi: 10.1136/oemed-2019-105849

8. Pintor EAS, Garbin ADC. Notificações de violência relacionadas ao trabalho e vigilância em saúde do trabalhador: rompendo a invisibilidade. Rev Bras Saúde Ocup. 2019;44:e20. doi: 10.1590/2317-6369000006918

9. Gooch PP. Hospital workplace violence prevention in California: new regulations. Workplace Health Saf. 2018;66(3):115-119. doi: 10.1177/2165079917731791

10. Wyatt R, Anderson-Drevs K, Van Male LM. Workplace violence in health care: a critical issue with a promising solution. JAMA. 2016;316(10):1037-8. doi: 10.1001/jama.2016.10384 